\title{
Attenuation of the Na/K-ATPase/Src/ROS amplification signaling pathway by astaxanthin ameliorates myocardial cell oxidative stress injury
}

\author{
XUEFENG QU*, ZHOUYI ZHANG*, WENLI HU, MINHAN LOU, BINGZHONG ZHAI, SONG MEI, \\ ZHIHANG HU, LIJING ZHANG, DONGYING LIU, ZHEN LIU, JIANGUO CHEN and YIN WANG \\ Zhejiang Academy of Medical Sciences, Hangzhou Medical College, Hangzhou, Zhejiang 310013, P.R. China
}

Received April 29, 2020; Accepted August 27, 2020

DOI: $10.3892 / \mathrm{mmr} .2020 .11613$

\begin{abstract}
The 3S, 3'S-ASTaxanthin (3S, 3'S-AST) isomer has strong antioxidant activity; however, its protective roles and potential mechanisms against oxidative stress damage in cardiomyocytes have not been investigated. $\mathrm{Na}^{+} / \mathrm{K}^{+}$-ATPase (NKA)/Src signal activation has an important role in increasing reactive oxygen species (ROS) production. The aim of the present study was to investigate the protective effects and mechanism of $3 \mathrm{~S}, 3$ 'S-AST on hydrogen peroxide $\left(\mathrm{H}_{2} \mathrm{O}_{2}\right)$-induced oxidative stress injury in $\mathrm{H} 9 \mathrm{c} 2$ myocardial cells. The protective effects of 3S, 3'S-AST on $\mathrm{H}_{2} \mathrm{O}_{2}$-induced $\mathrm{H} 9 \mathrm{c} 2$ cell injury was observed by measuring lactate dehydrogenase and creatine kinase myocardial band content, cell viability and nuclear morphology. The antioxidant effect was investigated by analyzing ROS accumulation and malondialdehyde, glutathione (GSH) peroxidase, GSH and glutathione reductase activity levels. The protein expression levels of Bax, Bcl-2, caspase-3 and cleaved caspase-3 were analyzed using western blotting to determine cardiomyocyte apoptosis. Western blot analysis of the phosphorylation levels of Src and Erk1/2 were also performed to elucidate the molecular mechanism involved. The results showed that 3S, 3'S-AST reduced the release of LDH and promoted cell viability, and attenuated ROS accumulation and cell apoptosis induced by $\mathrm{H}_{2} \mathrm{O}_{2}$. Furthermore, 3S, 3'S-AST also restored apoptosis-related $\mathrm{Bax}$ and $\mathrm{Bcl}-2$ protein expression levels in $\mathrm{H}_{2} \mathrm{O}_{2}$-treated $\mathrm{H} 9 \mathrm{c} 2$ cells. The phosphorylation levels of Src and Erk1/2 were significantly higher in the $\mathrm{H}_{2} \mathrm{O}_{2}$ treatment group, whereas $3 \mathrm{~S}$, 3'S-AST pretreatment significantly decreased the
\end{abstract}

Correspondence to: Professor Yin Wang, Zhejiang Academy of Medical Sciences, Hangzhou Medical College, 182 Tianmushan Road, Hangzhou, Zhejiang 310013, P.R. China

E-mail:wy3333@163.com

*Contributed equally

Key words: astaxanthin, reactive oxygen species, $\mathrm{Na}^{+} / \mathrm{K}^{+}$-ATPase, Src, apoptosis levels of phosphorylated (p)-Src and p-ERK1/2. The results provided evidence that $3 \mathrm{~S}, 3$ 'S-AST exhibited a cardioprotective effect against oxidative stress injury by attenuating NKA/Src/Erk1/2-modulated ROS amplification.

\section{Introduction}

Acute myocardial infarction (MI) is a common cause of death worldwide. The annual mortality and morbidity rates following MI are 7 and 22\%, respectively (1). Reperfusion therapies, including primary percutaneous coronary intervention and thrombolytic therapy, are commonly used to attenuate MI damage (2). However, reperfusion therapies may cause myocardial ischemia reperfusion (I/R) injury when the blood flow returns to the myocardial tissue (2). The potential molecular mechanisms of I/R injury include oxidative stress, inflammation, calcium overload and cytokine release (3). A large number of reactive oxygen species (ROS) are produced within minutes of reperfusion, which could oxidize target proteins to trigger oxidative stress injury, as a physiological second messenger signaling molecule (4). Abundant natural biologically active substances from diverse sources (e.g. luteolin, coptisine, curcumin) can potentially decrease I/R injury through an antioxidant effect (5-7). Therefore, natural biologically active substances can be used to control the development of oxidative stress injury in order to improve the health of patients with I/R.

Astaxanthin (AST) belongs to a natural xanthophyll carotenoid that is well-known for its antioxidant, antiinflammatory, anti-apoptosis and anticancer abilities (8-13). Haematococcus pluvialis (H. pluvialis) is the best natural AST resource as it primarily contains the 3S, 3'S-AST isomer. The 3S, 3'S-AST molecule is regarded as the most effective biological antioxidant to eliminate free radicals (14). AST has an $\alpha$-hydroxyketone structure, which is responsible for its strong antioxidant activity by capturing singlet oxygen and reacting with free radicals (15). The antioxidant activity of AST is 500 times and 10 times higher compared with that in vitamin $\mathrm{E}$ and $\beta$-carotene, respectively $(14,16)$. In recent years, AST has been reported to protect against cardiovascular disease. In rats with isoproterenol-induced MI, AST treatment decreased the weight of the heart, inflammatory cell 
infiltration and myocardial fibrosis by improving antioxidant enzyme activity (9). Furthermore, AST also attenuated cardiac dysfunction and fibrosis in a mouse MI model (17). However, the protective roles of $3 \mathrm{~S}, 3$ 'S-AST against ROS-induced damage of cardiomyocytes and the potential mechanisms involved have not been elucidated.

During I/R injury, cardiac $\mathrm{Na}^{+} / \mathrm{K}^{+}$-ATPase (NKA) function was found to be altered, and elucidation of the mechanism involved would be important to develop novel approaches for therapeutic intervention (18). NKA is a transmembrane enzyme responsible for transporting $\mathrm{Na}^{+}$ and $\mathrm{K}^{+}$ions across the cytomembrane, which establishes and maintains the ion concentration gradient across the cell plasma membrane (19). In addition to its $\mathrm{Na}$ pump function, NKA was also discovered to function as a signal transduction protein. The NKA/Src/Erk1/2 signaling pathway was found to be used as a feed-forward amplifier for ROS signaling that aggravates atherosclerosis, dyslipidemia, obesity and diabetes (20,21). Wang et al (22) demonstrated that ROS could active the NKA/Src/Erk1/2 signaling pathway to further trigger ROS production. Emerging studies have demonstrated the NKA/Src/ROS signal pathway is an underlying target for protecting the heart from I/R injury (23). Therefore, the present study was designed to investigate whether 3S, 3'S-AST exerts protective effects against myocardial oxidative stress damage by attenuating NKA/Src/Erk1/2 signaling-modulated ROS amplification.

\section{Materials and methods}

Materials. The 3S, 3'S-AST compound was obtained from Sigma-Aldrich (cat. no. SML0982; Merck KGaA), with $\geq 97 \%$ purity. Antibodies against Bax (cat. no. 2772S), Bcl-2 (cat. no. 3498S), caspase-3 (cat. no. 9665S), cleaved-caspase-3 (cat. no. 9664S), Erk1/2 (cat. no. 4695S) and phosphorylated (p)-Erk1/2 (Thr202/Tyr204; cat. no. 9101S) were purchased from Cell Signaling Technology, Inc. NKA (cat. no. cs-58629) and anti-c-Src antibodies (cat. no. cs8056) were obtained from Santa Cruz Biotechnology, Inc., while anti-p-Src pY418 antibody (cat. no. 44-660G) was obtained from Thermo Fisher Scientific, Inc. Goat anti-rabbit IgG (cat. no. 925-68021) and goat anti-mouse IgG (cat. no. 925-68020) secondary antibodies were purchased from LI-COR Biosciences. Nitrocellulose (NC) membranes were purchased from EMD Millipore, while RIPA lysis buffer was purchased from Boster Biological Technology. FBS was obtained from Biological Industries and the MTT kit (cat. no. M2128) and DAPI fluorescent dye (cat. no. D9542) were purchased from Sigma-Aldrich (Merck KGaA).

Cell culture and treatment. $\mathrm{H} 9 \mathrm{c} 2$ cells (rat embryonic cardiomyocytes) were obtained from the Cell Bank of Shanghai Academy of Sciences and cultured in DMEM (cat. no. C11995500BT; Gibco; Thermo Fisher Scientific, Inc.) supplemented with $10 \%$ FBS and $1 \%$ penicillin-streptomycin at $37^{\circ} \mathrm{C}$ in a humidified incubator with $5 \% \mathrm{CO}_{2}$. The $\mathrm{H} 9 \mathrm{c} 2$ cells were passaged regularly and cultured to $70-80 \%$ confluence prior experimentation. Control group was treated with DMEM without FBS; DMSO group was treated with DMEM and DMSO without FBS. To generate a ROS-induced myocardial cell injury model, $\mathrm{H} 9 \mathrm{c} 2$ cells were exposed to $100 \mu \mathrm{M} \mathrm{H}_{2} \mathrm{O}_{2}$ for 1 or $24 \mathrm{~h}$ and analyzed for further analysis. A total of $50 \mathrm{mg}$ 3S, 3'S-AST powder was dissolved in $5 \mathrm{ml}$ DMSO and prepared into a stock solution of $16.8 \mathrm{mM}$. Cells were pretreated with $3 \mathrm{~S}, 3$ 'S-AST $(5,10$ and $20 \mu \mathrm{M})$ for $1 \mathrm{~h}$ prior to $\mathrm{H}_{2} \mathrm{O}_{2}$ administration.

Cell viability assay. Cell viability was detected using an MTT kit according to the manufacturer's instructions. H9c2 cells were plated into 96 -well plates $\left(1 \times 10^{3}\right.$ cells/well $)$, cultured with DMEM and treated with 3S, 3'S-AST $(5,10,20 \mu \mathrm{M})$ and $\mathrm{H}_{2} \mathrm{O}_{2}$ $(50,100,200,400 \mu \mathrm{M})$ for $24 \mathrm{~h}$. A total of $15 \mu \mathrm{l}$ MTT solution was added into each well and co-incubated for $4 \mathrm{~h}$, at $37^{\circ} \mathrm{C}$. After removing the medium, $150 \mu \mathrm{l}$ DMSO was added to each well. The absorbance was measured at a wavelength of $490 \mathrm{~nm}$ using a microplate absorbance reader (Multiskan; Thermo Fisher Scientific, Inc.) and analyzed to assess cell viability.

Cell apoptosis assay. To detect cell apoptosis, H9c2 cells were stained using a DAPI fluorescent dye to observe nuclear morphology. H9c2 cells were plated into six-well plates (1x $10^{5}$ cells/well), washed with PBS three times and fixed in $4 \%$ paraformaldehyde (Beyotime Institute of Biotechnology) at room temperature for $10 \mathrm{~min}$. The cells were then washed three times with PBS and stained using $3 \mathrm{ml}$ DAPI staining solution $(1 \mu \mathrm{g} / \mathrm{ml})$ for $10 \mathrm{~min}$ at $37^{\circ} \mathrm{C}$. The nuclear morphology was observed using fluorescence microscopy (Olympus Corporation; magnification, x200). Healthy living cells presented with uniform staining of the nuclei. Apoptotic cells presented with pyknosis and fragmentation of the nuclei.

Lactate dehydrogenase $(\mathrm{LDH})$ release analysis. Cell damage was determined using an LDH assay kit (cat. no. A020; Nanjing Jiancheng Bioengineering Institute) by detecting LDH release of myocardial cells. H9c2 cells were cultured at a density of $1 \times 10^{5}$ cells/well in six-well plates. A total of $20 \mu 1$ cell culture medium was added into another 96-well plate, with $300 \mu \mathrm{l}$ reaction mixture from the kit and the mixture was incubated for $30 \mathrm{~min}$ at $37^{\circ} \mathrm{C}$. LDH activity was measured using a microplate reader at a wavelength of $450 \mathrm{~nm}$.

Creatine kinase-myocardial band $(C K-M B)$ activity analysis. CK-MB activity levels were measured using a CK-MB assay kit (cat. no. E006; Nanjing Jiancheng Bioengineering Institute) according to manufacturer's protocol. Briefly, H9c2 cells were lysed with PBS buffer, and freeze/thawed three times on ice for $30 \mathrm{~min}$, followed by centrifugation at $12,000 \mathrm{x} \mathrm{g}$ for $15 \mathrm{~min}$ at $4^{\circ} \mathrm{C}$ to isolate the cell debris. The protein content of samples was examined using a bicinchoninic acid (BCA) protein assay kit (Beyotime Institute of Biotechnology). CK-MB activity levels were detected at a wavelength of $340 \mathrm{~nm}$ using a microplate absorbance reader and expressed as U/g protein.

Malondialdehyde (MDA) and glutathione peroxidase (GSH-px) level detection. The levels of MDA and GSH-px in $\mathrm{H} 9 \mathrm{c} 2$ cells were detected using MDA (cat. no. A003) and GSH-px assay kits (cat. no. A005) (both from Nanjing Jiancheng Bioengineering Institute) according to the manufacturer's instructions. Briefly, H9c2 cells were lysed with PBS buffer and freeze/thawed 3 times on ice for $30 \mathrm{~min}$. The 
supernatant was isolated by centrifugation at $12,000 \mathrm{x} \mathrm{g}$ for $15 \mathrm{~min}$ at $4^{\circ} \mathrm{C}$. The MDA content was measured at a wavelength of $532 \mathrm{~nm}$ and expressed as nmol/mg protein. The GSH-px activities of the cell lysate was detected at a wavelength of $412 \mathrm{~nm}$ according to the produced enzyme-catalyzed reaction product.

GSH and glutathione reductase (GR) level detection. The levels of GSH and GR in H9c2 cells were detected using GSH (cat. no. A006) and GR assay kits (cat. no. A062) (both from Nanjing Jiancheng Bioengineering Institute) according to the manufacturer's instructions. Briefly, the H9c2 cells were lysed with PBS buffer and freeze/thawed three times on ice for $30 \mathrm{~min}$ then. The mixture was then centrifuged at $12,000 \mathrm{x} \mathrm{g}$ for $15 \mathrm{~min}$ at $4^{\circ} \mathrm{C}$ to isolate the cell debris. GSH activity levels were detected at a wavelength of $405 \mathrm{~nm}$ and expressed as $\mu \mathrm{mol} / \mathrm{g}$ protein, while GR activity levels were detected at a wavelength of $340 \mathrm{~nm}$ using a spectrophotometer and expressed as $\mathrm{U} / \mathrm{g}$ protein.

Intracellular ROS measurements. A ROS assay kit (cat. no. S0033; Beyotime Institute of Biotechnology) was used to detect intracellular ROS levels according to the manufacturer's instructions. 2'-7'-dichlorofluorescin diacetate (DCFH-DA) was diluted with serum-free medium (1:1,000). Cells were seeded into a six-well plate $\left(1 \times 10^{5}\right.$ cells/well) and treated with $\mathrm{H}_{2} \mathrm{O}_{2}$ and $3 \mathrm{~S}, 3$ 'S-AST for $24 \mathrm{~h}$. The culture medium was removed and the cells were incubated with DCFH-DA $(10 \mu \mathrm{M})$ for $20 \mathrm{~min}$ at $37^{\circ} \mathrm{C}$. Subsequently, the cells were washed with serum-free medium (three times for $5 \mathrm{~min}$ each time) and images were obtained using a fluorescence microscope (Olympus Corporation; magnification x100). ROS fluorescence intensity was analyzed using Image-Pro Plus (version 5.0; MediaCybernetics, Inc.).

Western blot analysis. Following treatment, H9c2 cells were scraped using a scraper and the protein lysates were extracted using a solubilization buffer (containing RIPA and $1 \%$ protease inhibitor). The debris was removed by centrifugation at $12,000 \mathrm{x}$ g for $15 \mathrm{~min}$ at $4^{\circ} \mathrm{C}$. The protein concentration was determined using a BCA assay kit. The protein samples $(80 \mu \mathrm{g})$ were added to $5 \mathrm{X}$ loading buffer (Beyotime Institute of Biotechnology) and heated at $95^{\circ} \mathrm{C}$ for 5 min using metal heating block. Protein samples were separated using 10\% SDS-PAGE and transferred onto a NC membrane, at a constant current of $300 \mathrm{~mA}$ for $1 \mathrm{~h}$ under wet transfer conditions. The NC membranes were blocked with $5 \%$ skimmed milk at room temperature, and the proteins were incubated with the following antibodies overnight at $4{ }^{\circ} \mathrm{C}$ : NKA (1:200), c-Src (1:200), p-Src (1:1,000), Erk1/2 (1:1,000), p-Erk1/2 (1:1,000), Bax (1:500), Bcl-2 (1:500), caspase-3 (1:500), cleaved-caspase-3 (1:500) and GAPDH $(1: 1,000)$. The membranes were then incubated with the following fluorescent secondary antibodies: Goat anti-rabbit $(1: 10,000)$ and goat anti-mouse $(1: 10,000)$. The bands were captured and quantified using an Odyssey Imaging System (LI-COR Biosciences).

Statistical analysis. Statistical analysis was performed using SPSS software (version 22.0; IBM Corp.). The results are represented as the mean \pm SEM from at least three independent experiments. Analysis between two groups were performed using Student's t-test. Analysis between multiple groups were performed using one-way ANOVA analysis followed by Tukey's post hoc test. $\mathrm{P}<0.05$ was considered to indicate a statistically significant difference.

\section{Results}

3S, 3'S-AST attenuates ROS-induced cell injury in rat cardiomyocytes. To investigate the protective effects of 3S, 3'S-AST in cardiomyocytes under oxidative stress damage in vitro, the rat $\mathrm{H} 9 \mathrm{c} 2$ embryonic heart-derived cell line was treated with $\mathrm{H}_{2} \mathrm{O}_{2}$ to simulate oxidative stress injury. The cell viability was evaluated using an MTT assay. As shown in Fig. $1 \mathrm{~A}$ and $\mathrm{B}, \mathrm{H}_{2} \mathrm{O}_{2}$ significantly decreased cell viability in $\mathrm{H} 9 \mathrm{c} 2$ cells in dose-dependent manner, and pretreatment with 3S, 3'S-AST significantly inhibited the decrease of cell viability caused by $\mathrm{H}_{2} \mathrm{O}_{2}$. Furthermore, with the increase in the dose of 3S, 3'S-AST, the effect of inhibition was more significant. Because the $100 \mu \mathrm{M} \mathrm{H}_{2} \mathrm{O}_{2}$ decreased cell viability to $\sim 60 \%$, this concentration was used for subsequent experiments. LDH and CK-MB are well-known indicators of cell injury (24); Therefore, they were measured in the present study. The LDH content in the culture medium of $\mathrm{H}_{2} \mathrm{O}_{2}$-treated cells was significantly higher compared with the control group, and treatment with $\mathrm{H}_{2} \mathrm{O}_{2}$ significantly increased CK-MB content in $\mathrm{H} 9 \mathrm{c} 2$ cells. However, pretreatment with 3S, 3'S-AST significantly reduced this increase (Fig. 1C and D). No significant difference was observed in the $5 \mu \mathrm{M} 3 \mathrm{~S}, 3$ 'S-AST-treated group compared with the $\mathrm{H}_{2} \mathrm{O}_{2}$-treated group.

3S, 3'S-AST inhibits ROS-induced cardiomyocyte apoptosis. DAPI DNA fluorescent staining was utilized to investigate the effect of 3S, 3'S-AST on cell apoptosis. The morphology of the nucleus in the $\mathrm{H} 9 \mathrm{c} 2$ cells showed uniform staining in the control and DMSO groups. By contrast, $\mathrm{H}_{2} \mathrm{O}_{2}$-treated cells showed nuclear pyknosis and fragmentation. Compared with the $\mathrm{H}_{2} \mathrm{O}_{2}$-treated group, the $3 \mathrm{~S}, 3$ 'S-AST-treated group showed markedly attenuated cell apoptosis, but no significant difference was observed in the $5 \mu \mathrm{M} 3 \mathrm{~S}, 3$ 'S-AST-treated group ( $\mathrm{P}>0.05$ ) (Fig. 2A). Western blot analysis was performed to evaluate the effect of $3 \mathrm{~S}, 3$ 'S-AST on the expression levels of pro-apoptosis proteins (Bax, caspase-3 and cleaved-caspase-3) and anti-apoptosis protein (Bcl-2) in each group. The protein expression levels of caspase-3, cleaved-caspase-3 and Bax were significantly downregulated, while the expression level of Bcl-2 was significantly upregulated in the $3 \mathrm{~S}, 3$ 'S-AST-treated groups compared with the $\mathrm{H}_{2} \mathrm{O}_{2}$-treated group. These effects were attenuated treatment with 10 and $20 \mu \mathrm{M}$ 3S, 3'S-AST (Fig. 2B-F).

Effects of 3S, 3'S-AST on ROS accumulation and antioxidant activity. DCFH-DA staining was used to determine ROS accumulation. Cells treated with $3 \mathrm{~S}, 3$ 'S-AST significantly attenuated intracellular ROS level induced by $\mathrm{H}_{2} \mathrm{O}_{2}$ (Fig. 3A and B). It was reported that the NKA/Src signaling pathway, which regulates ROS amplification, plays a key role in oxidative stress damage (23). In the present study, the results indicated that 3S, 3'S-AST may act as an antioxidant to reduce the ROS level and inhibit the NKA/Src/ROS amplification loop. 

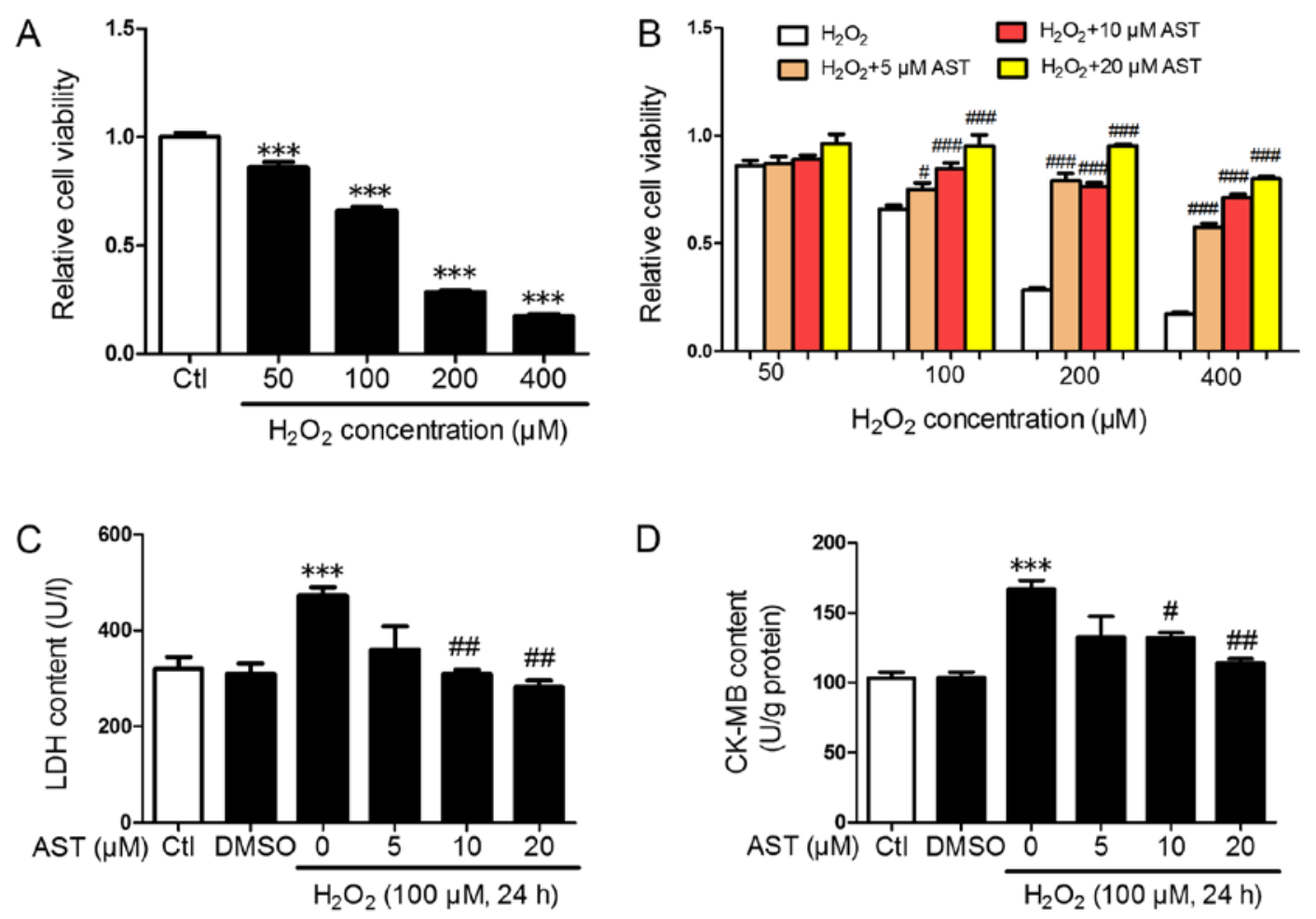

Figure 1.3S, 3'S-AST attenuates reactive oxygen species-induced injury in $\mathrm{H} 9 \mathrm{c} 2$ cells. (A) Cell viability in $\mathrm{H} 9 \mathrm{c} 2$ cells treated with different concentrations of $\mathrm{H}_{2} \mathrm{O}_{2}$ $(50,100,200$, and $400 \mu \mathrm{M})$ for $24 \mathrm{~h} . \mathrm{n}=8 .{ }^{* * *} \mathrm{P}<0.001$ vs. Ctl. (B) Cell viability in cells pretreated with various concentrations of 3S, 3'S-AST (5, 10 and $\left.20 \mu \mathrm{M}\right)$ for $1 \mathrm{~h}$, and then treated with $\mathrm{H}_{2} \mathrm{O}_{2} . \mathrm{n}=8 .{ }^{\#} \mathrm{P}<0.05$ and ${ }^{\# \# /} \mathrm{P}<0.001$ vs. $\mathrm{H}_{2} \mathrm{O}_{2} .(\mathrm{C}) \mathrm{H}_{2} \mathrm{O}_{2}(100 \mu \mathrm{M}, 24 \mathrm{~h})$ upregulated the $\mathrm{LDH}$ content in the culture supernatant of

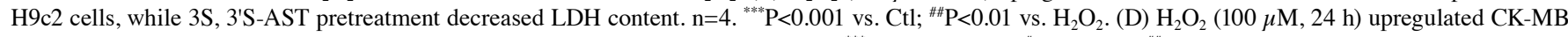
content in $\mathrm{H} 9 \mathrm{c} 2$ cells while $3 \mathrm{~S}, 3$ 'S-AST pretreatment decreased CK-MB content. $\mathrm{n}=3$. ${ }^{* * *} \mathrm{P}<0.001 \mathrm{vs}$. $\mathrm{Ctl}$; ${ }^{*} \mathrm{P}<0.05$ and ${ }^{\# \#} \mathrm{P}<0.01$ vs, $\mathrm{H}_{2} \mathrm{O}_{2}$. Data are expressed as the mean \pm standard error of the mean. AST, 3S, 3'S-ASTaxanthin; LDH, lactate dehydrogenase; CK-MB, creatine kinase-myocardial band; Ctl, control.

Furthermore, the effects of 3S, 3'S-AST on MDA content and GSH-px, GSH and GR activity levels were also measured. The results revealed that treatment with $\mathrm{H}_{2} \mathrm{O}_{2}$ significantly increased MDA content and significantly decreased GSH-px, GSH and GR activity levels in H9c2 cells. The effects of 10 and $20 \mu \mathrm{M}$ 3S, 3'S-AST were more effective compared with cells treated with $5 \mu \mathrm{M} 3 \mathrm{~S}, 3$ 'S-AST (Fig. 3C-F).

Effects of 3S, 3'S-AST on the NKA/Src signaling pathway. ROS is a specific ligand of NKA and could induce activation of Src and Erk1/2 and activated NKA/Src/Erk1/2 signaling further promoted ROS production (22). Therefore, the effects of 3S, 3'S-AST on the phosphorylation of Src and its downstream regulator Erk1/2 in $\mathrm{H}_{2} \mathrm{O}_{2}$-treated $\mathrm{H} 9 \mathrm{c} 2$ cells was determined. As shown in Figs. 4 and 5, the phosphorylation of Src and Erk1/2 was significantly upregulated in $\mathrm{H}_{2} \mathrm{O}_{2}$-treated cells compared with controls. However, $3 \mathrm{~S}, 3$ 'S-AST inhibited the activation of Src and Erk1/2 and did not alter the protein expression levels of NKA in cells with ROS-induced damage. These results indicated that 3S, 3'S-AST attenuated the activities of the NKA/Src/Erk1/2 signaling pathway, which acted as one upstream pathway of ROS production and apoptosis.

\section{Discussion}

Restoring blood flow has been confirmed to be an efficient approach to recover ischemic myocardium (25). However, myocardial reperfusion will elicit an increase in ROS production in cardiomyocytes (26). Some therapeutic drugs, such as rosuvastatin (27), have been available to prevent oxidative stress injury from I/R; however, the therapeutic effects for I/R injury remain unsatisfactory (28). Therefore, it is essential to discover safe and effective therapeutic agents. The present study demonstrated the function of 3S, 3'S-AST in protecting cardiomyocytes from ROS-induced injury in vitro. The results indicated that $3 \mathrm{~S}, 3^{\prime} \mathrm{S}-\mathrm{AST}$ treatment inhibited cardiomyocyte apoptosis and improved antioxidant activity. It was further indicated that $3 \mathrm{~S}, 3$ 'S-AST treatment prevented intracellular ROS generation by reducing the activity of the NKA/Src/Erk1/2/ROS amplification signal transduction pathway.

AST exists in three stereoisomeric forms (3S, 3'S; 3R, 3'R and 3R, 3'S)(29). H. pluvialis-derived AST primarily contains the $3 \mathrm{~S}, 3$ 'S-form, and synthetic AST is a mixture of the three stereoisomers [(3S, 3'S):(3R, 3'S):(3R, 3'R), 1:2:1 ratio] (29). It was reported that synthetic AST could reduce MI size in I/R rabbits (30); however, humans are unable to use synthetic AST (31), while $H$. pluvialis-derived AST is the only AST permitted for human consumption (31). Synthetic AST has 20 times lower antioxidant capacity than natural AST and to date has not been approved for human consumption. The United States Food and Drug Administration and the European Food Safety Authority has approved the use of AST from H.pluvialis, as a food ingredient in the food production process and it can be used as an additive at dosages below $12-24 \mathrm{mg} /$ day within 30 days (32). Initial preclinical studies also support the antioxidant ability of AST at a particular dose. For example, 
A

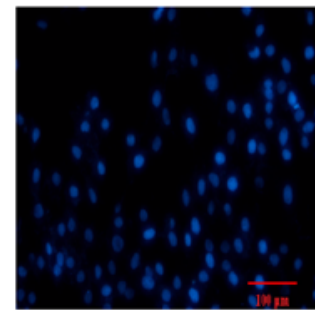

Ctl

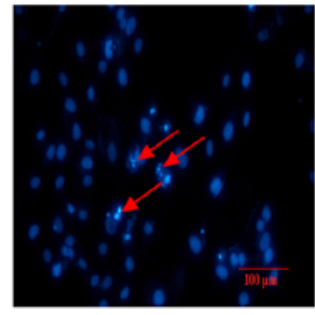

$\mathrm{H}_{2} \mathrm{O}_{2}+5 \mu \mathrm{M}$ AST

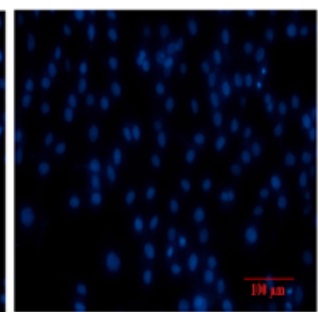

DMSO

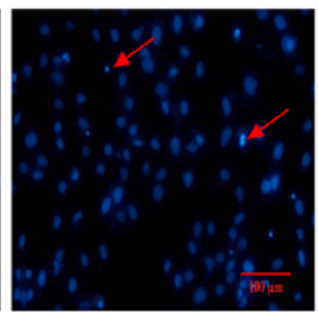

$\mathrm{H}_{2} \mathrm{O}_{2}+10 \mu \mathrm{M}$ AST

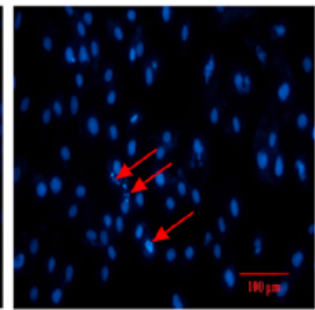

$\mathrm{H}_{2} \mathrm{O}_{2}$

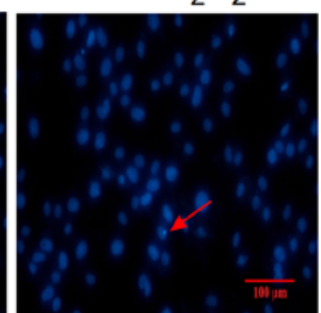

$\mathrm{H}_{2} \mathrm{O}_{2}+20 \mu \mathrm{M}$ AST

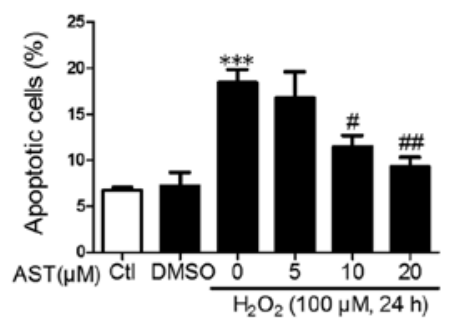

B

$\mathrm{H}_{2} \mathrm{O}_{2}(100 \mu \mathrm{M}, 24 \mathrm{~h})$

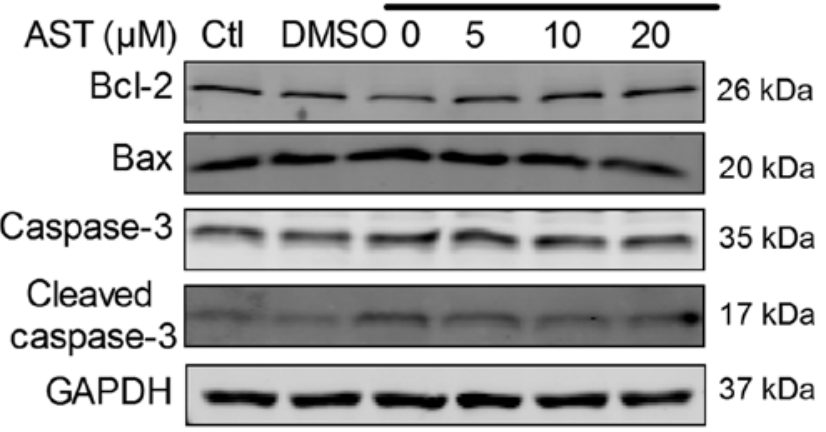

C
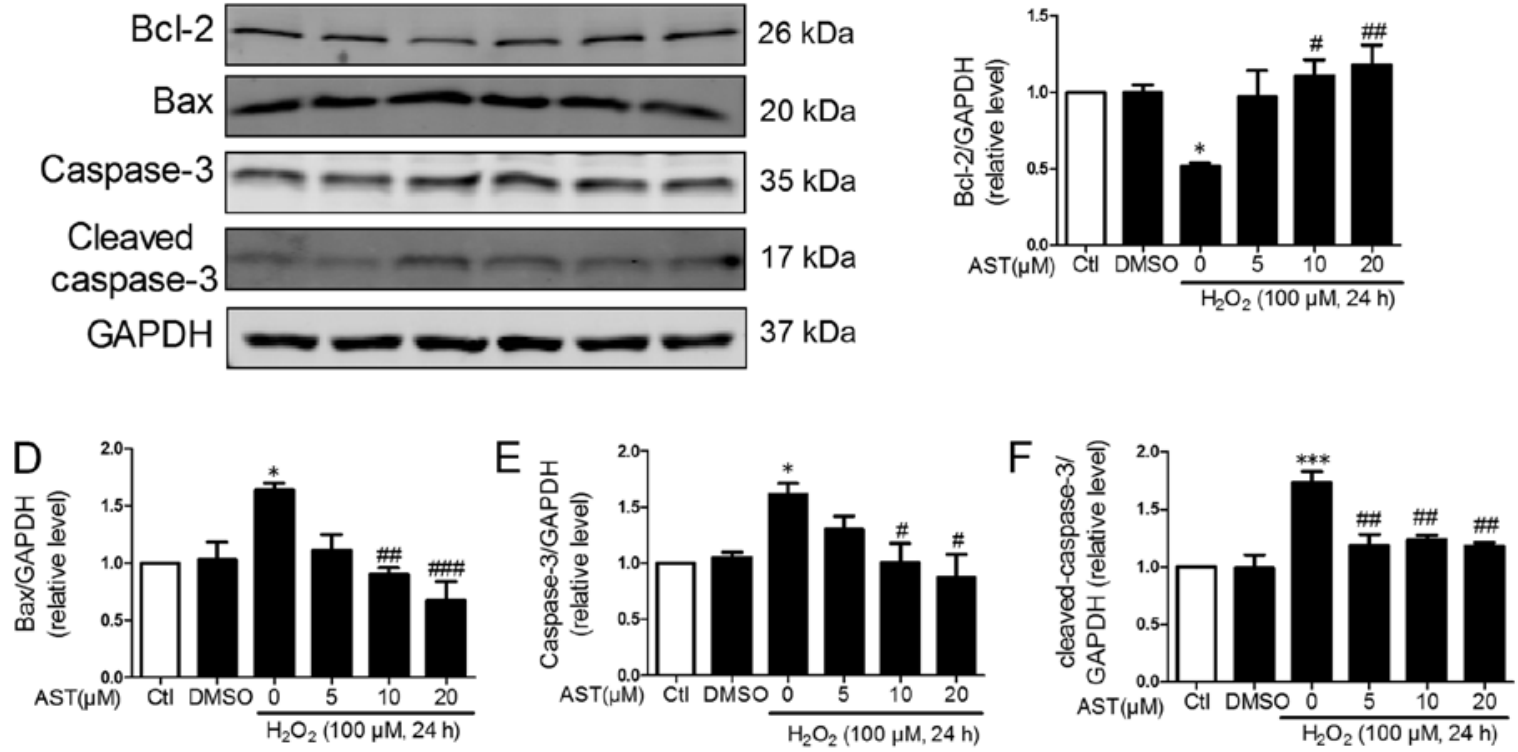

Figure 2. 3S, 3'S-AST attenuates reactive oxygen species-induced cell apoptosis. (A) Pretreatment with 3S, 3'S-AST decreased the number of apoptotic cells caused by treatment with $\mathrm{H}_{2} \mathrm{O}_{2}(100 \mu \mathrm{M}, 24 \mathrm{~h})$. The red arrows indicate apoptotic cells. Scale bar, $100 \mu \mathrm{M}$. (B) Expression levels of Bcl-2, Bax, caspase-3 and cleaved-caspase-3 were determined by western blot analysis. Densitometric analysis of (C) Bcl-2, (D) Bax, (E) caspase-3 and (F) cleaved-caspase-3. Data are expressed as the mean \pm standard error of the mean. $n=3$. ${ }^{*} \mathrm{P}<0.05$ and ${ }^{* * *} \mathrm{P}<0.001$ vs. Ctl; ${ }^{\#} \mathrm{P}<0.05,{ }^{\# \#} \mathrm{P}<0.01$ and ${ }^{\# \# \#} \mathrm{P}<0.001$ vs. $\mathrm{H}_{2} \mathrm{O}_{2}$. AST, $3 \mathrm{~S}, 3$ 'S-AST. AST, 3S, 3'S-ASTaxanthin; Ctl, control.

Iwamoto et al (33) found that the resistance of volunteers to low-density lipoprotein oxidation was enhanced when AST was administered at doses of 1.8-21.6 mg/day for 14 days. Yoshida et al (34) showed that triglyceride and high-density lipoprotein-cholesterol levels were ameliorated in patients administered with AST at doses of 12-18 mg/day for 12 weeks. Furthermore, in a human clinical study, the beneficial action of dietary AST was identified at doses of 2 and $8 \mathrm{mg} / \mathrm{day}$ for 8 days and was found to regulate the immune response, oxidative damage and inflammation (35). However, a previous study investigating the anti-fibrotic effects of different concentrations of AST $(10,20$ and $40 \mu \mathrm{M})$ on LX-2 cells revealed that AST could modulate proliferation and apoptosis of LX-2 cells at the cellular level (36). H9c2 cells pre-treated with
0.5-8 $\mu \mathrm{M}$ AST for $6 \mathrm{~h}$ and co-incubated with homocysteine for $72 \mathrm{~h}$ revealed that AST alleviated homocysteine induced cytotoxicity (37). In the present study, different concentrations of 3S, 3'S-AST $(5,10$ and $20 \mu \mathrm{M})$ was used to treat $\mathrm{H} 9 \mathrm{c} 2$ cells to investigate the effects and mechanism of $3 \mathrm{~S}, 3$ 'S-AST on oxidative stress. It was found that 10 and $20 \mu \mathrm{M} 3 \mathrm{~S}, 3$ 'S-AST was more effective compared with that for $5 \mu \mathrm{M}$, and almost no significant difference was observed in cells treated with $5 \mu \mathrm{M} 3 \mathrm{~S}, 3$ 'S-AST compared with $\mathrm{H}_{2} \mathrm{O}_{2}$-treated cells.

The bioavailability of AST is affected a number of factors, including host-related conditions, such as sex, age, obesity, smoking and alcohol consumption, as well as the structure of AST or its dispersion medium (14). Some trials have investigated the bioavailability of AST from $H$. pluvialis under 
A

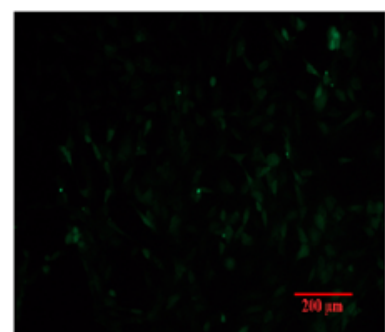

Ctl

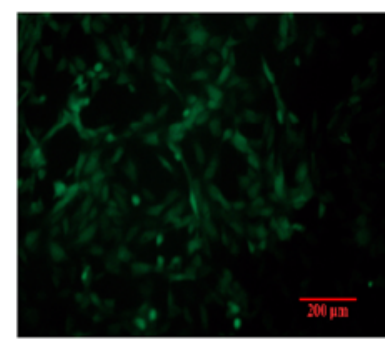

$\mathrm{H}_{2} \mathrm{O}_{2}+5 \mu \mathrm{M}$ AST

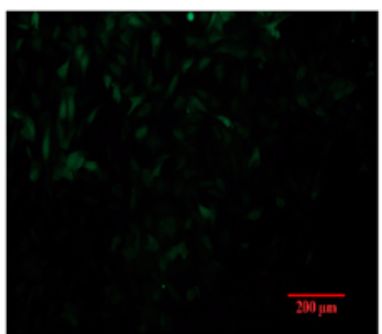

DMSO

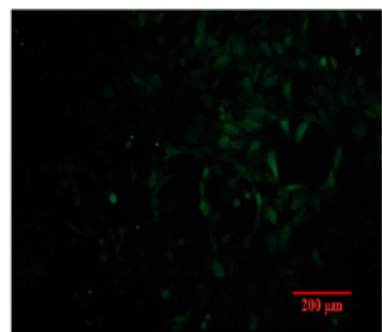

$\mathrm{H}_{2} \mathrm{O}_{2}+10 \mu \mathrm{M}$ AST

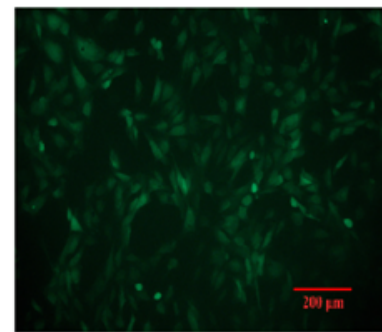

$\mathrm{H}_{2} \mathrm{O}_{2}$

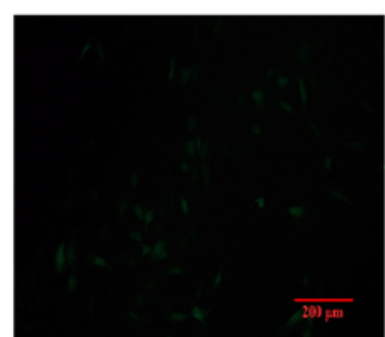

$\mathrm{H}_{2} \mathrm{O}_{2}+20 \mu \mathrm{M}$ AST
B

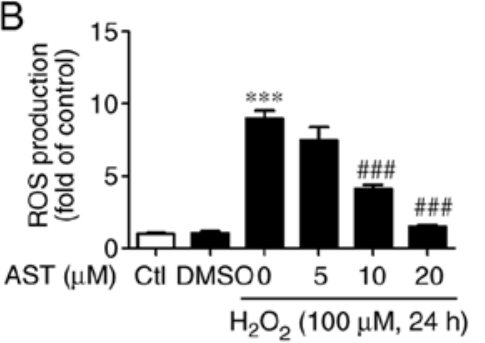

C

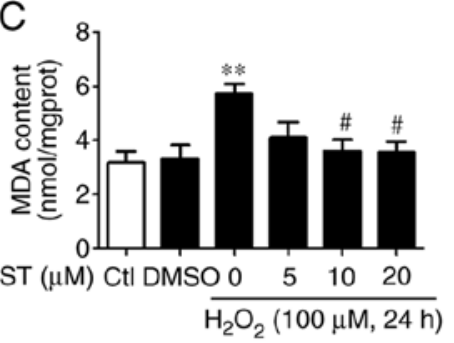

D

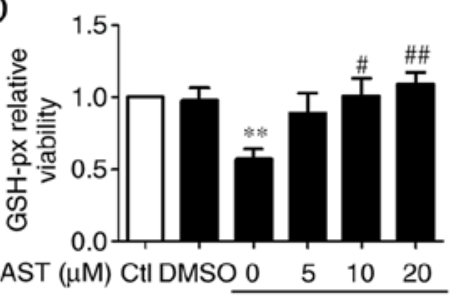

E

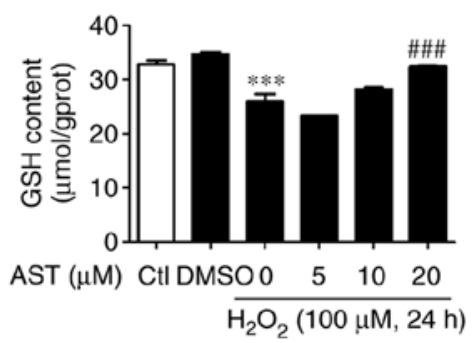

$\mathrm{F}$

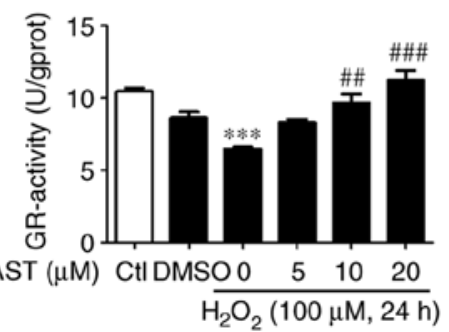

Figure 3. 3S, 3'S-AST inhibits ROS-induced ROS accumulation and increases antioxidation activity. (A) Representative ROS staining in H9c2 cells treated with $\mathrm{H}_{2} \mathrm{O}_{2}(100 \mu \mathrm{M}, 24 \mathrm{~h})$ and pretreated with 3S, 3'S-AST. Scale bar, $200 \mu \mathrm{M}$. (B) Quantitative analysis of ROS fluorescence intensity. n=3. (C) Pretreatment with 3S, 3'S-AST decreased MDA content in $\mathrm{H} 9 \mathrm{c} 2$ cells treated with $\mathrm{H}_{2} \mathrm{O}_{2}(100 \mu \mathrm{M}, 24 \mathrm{~h}) . \mathrm{n}=4$. (D) Pretreatment with 3S, 3'S-AST increased GSH-px activity in $\mathrm{H} 9 \mathrm{c} 2$ cells treated with $\mathrm{H}_{2} \mathrm{O}_{2}(100 \mu \mathrm{M}, 24 \mathrm{~h}) . \mathrm{n}=3$. (E) Pretreatment with $3 \mathrm{~S}, 3$ 'S-AST increased GSH content in $\mathrm{H}_{9} \mathrm{c} 2$ cells treated with $\mathrm{H}_{2} \mathrm{O}_{2}$ ( $\left.100 \mu \mathrm{M}, 24 \mathrm{~h}\right)$. $\mathrm{n}=3$. (F) Pretreatment with $3 \mathrm{~S}, 3$ 'S-AST increased GR activity in $\mathrm{H} 9 \mathrm{c} 2$ cells treated with $\mathrm{H}_{2} \mathrm{O}_{2}(100 \mu \mathrm{M}, 24 \mathrm{~h})$. $\mathrm{n}=3$. Data are expressed as the mean \pm standard error of the mean. ${ }^{* *} \mathrm{P}<0.01,{ }^{* * *} \mathrm{P}<0.001$ vs. $\mathrm{Ctl}$; ${ }^{\#} \mathrm{P}<0.05,{ }^{\# \#} \mathrm{P}<0.01$ and ${ }^{\# \# \#} \mathrm{P}<0.001$ vs. $\mathrm{H}_{2} \mathrm{O}_{2}$. AST, 3S, 3'S-ASTaxanthin; Ctl, control; ROS $<$, reactive oxygen species; MDA, malondialdehyde; GSH-px, glutathione peroxidase; GR, glutathione reductase; GSH, glutathione.

different factors. Okada et al (38) showed that the metabolism of AST in a group of smokers was faster compared with the non-smokers group, which may be attributed to the antioxidant effect of AST. A previous study found that dietary oils may enhance the absorption of AST bioavailability in humans (39). In addition, Mercke et al (40) determined the bioavailability of AST from $H$. pluvialis dispersed in synthetic hydrophilic surfactant polysorbate 80 (B), which is a lipid-based formulation, was 1.7-3.7 times higher compared with the commercial formulation. Furthermore, studies have shown that the antioxidant ability of AST from $H$. pluvialis was improved in rat plasma and liver tissues after being dissolved in olive oil $(41,42)$. Satoh et al $(43)$ administered participants with an oil-based natural AST-rich product for 4 weeks at $20 \mathrm{mg}$ daily, and there were no safety concerns reported by evaluating toxicity and efficacy levels. As aforementioned, further research should focus on improving host-related conditions and identifying new biomaterials to act as astaxanthin vectors to improve its bioavailability.

Baburina et al (44) revealed that AST could inhibit opening of a large-conductance channel (mitochondrial permeability transition pore) in the rat heart following mitochondrial calcium overload or oxidative stress by reducing the serine/threonine protein kinase B/cAMP-responsive element-binding protein signaling pathways in the mitochondria. Nakao et al (45) found that $0.08 \%$ AST had a significantly positive effect on cardiac function of mice. AST treatment reversed enhanced lipid peroxidation and reduced antioxidant enzyme activities 
A

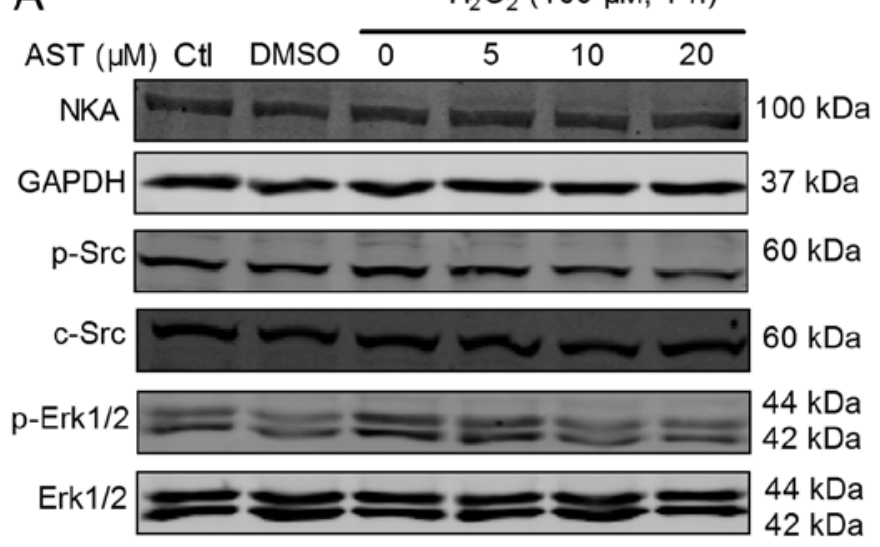

B
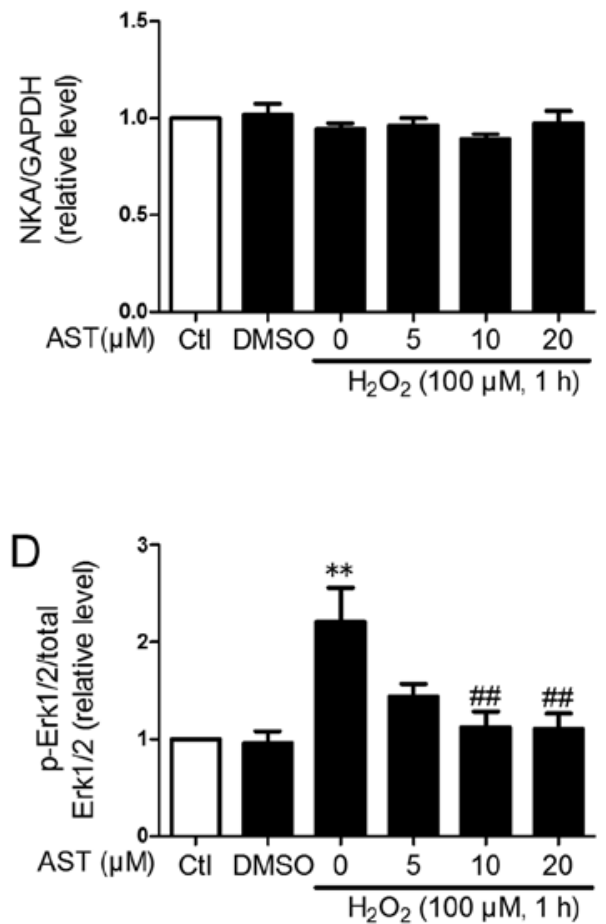

Figure 4. Effects of 3S, 3'S-AST on the NKA/Src/Erk1/2 signaling pathway. (A) Levels of NKA, p-Src and p-Erk1/2 were determined by western blot analysis in $\mathrm{H} 9 \mathrm{c} 2$ cells treated with $\mathrm{H}_{2} \mathrm{O}_{2}(100 \mu \mathrm{M}, 1 \mathrm{~h})$ and pretreated with $3 \mathrm{~S}, 3$ 'S-AST. Densitometric analysis of (B) NKA, (C) p-Src and (D) p-Erk1/2. Data

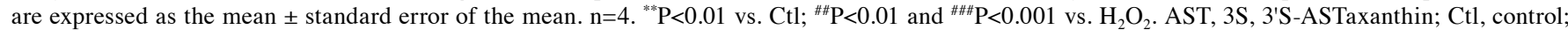
p, phosphorylated; NKA, $\mathrm{Na}^{+} / \mathrm{K}^{+}$-ATPase.

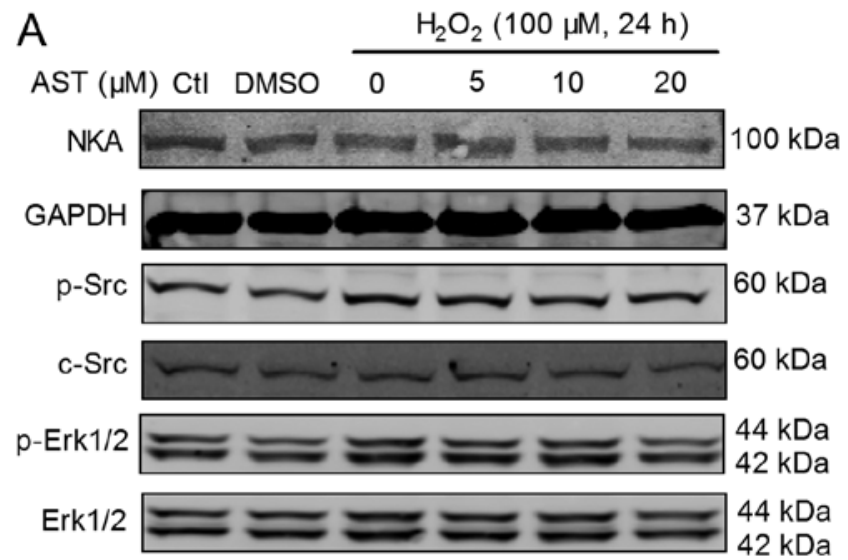

B

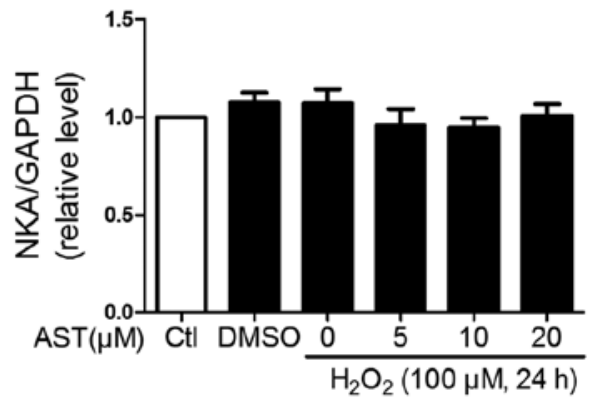

C
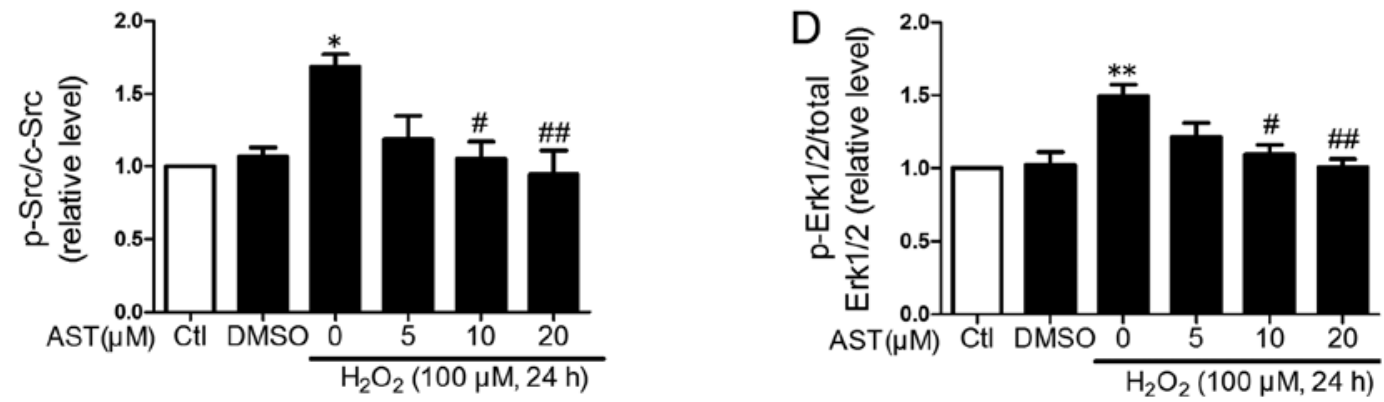

Figure 5. Effects of 3S, 3 'S-AST on the NKA/Src/Erk1/2 signaling pathway. (A) Levels of NKA, p-Src and p-Erk1/2 were determined by western blot analysis in $\mathrm{H} 9 \mathrm{c} 2$ cells treated with $\mathrm{H}_{2} \mathrm{O}_{2}(100 \mu \mathrm{M}, 24 \mathrm{~h})$ and pretreated with 3S, 3'S-AST. Densitometric analysis of (B) NKA, (C) p-Src and (D) p-Erk1/2. Data are expressed as the mean \pm standard error of the mean. $\mathrm{n}=3$. ${ }^{*} \mathrm{P}<0.05$ and ${ }^{* *} \mathrm{P}<0.01$ vs. $\mathrm{Ctl} ;{ }^{*} \mathrm{P}<0.05$ and ${ }^{\# \#} \mathrm{P}<0.01$ vs. $\mathrm{H}_{2} \mathrm{O}_{2}$. AST, 3S, 3'S-ASTaxanthin; Ctl, control; p, phosphorylated; NKA, $\mathrm{Na}^{+} / \mathrm{K}^{+}$-ATPase. 
in heart tissues caused by isoproterenol (ISO) administration in rats, which suggested that AST may protect cardiac tissue in ISO-administered rats by suppressing oxidative stress and enhancing antioxidant enzyme functions (9). However, the effects and mechanism of $3 \mathrm{~S}, 3$ 'S-AST on oxidative stress injury in myocardial cells caused by $\mathrm{I} / \mathrm{R}$ was unknown. In the current study, oxidative stress injury in the $\mathrm{H} 9 \mathrm{c} 2$ cells induced by $\mathrm{H}_{2} \mathrm{O}_{2}$ was used to mimic I/R injury. It was found that $3 \mathrm{~S}, 3$ 'S-AST significantly increased cell viability in $\mathrm{H}_{2} \mathrm{O}_{2}$-treated $\mathrm{H} 9 \mathrm{c} 2$ cells. $\mathrm{LDH}$ and $\mathrm{CK}-\mathrm{MB}$ are known to be markers of cell injury, and release of LDH and content of CK-MB were significantly reduced by $3 \mathrm{~S}, 3$ 'S-AST.

AST shows effective anti-apoptosis, anti-inflammatory, anti-cancer, and cardioprotective capacities, which were associated with its antioxidant activity $(14,29)$. ROS is a universal inducer of myocardial apoptosis in reperfusion injury (46). Excessive ROS production has been considered to be important to induce I/R injury (46). MDA is the end product of the lipid peroxidation reaction; therefore, the content of MDA could reflect the degree of lipid peroxidation (47). To protect molecules from ROS, cells stimulate antioxidant defense systems, including GSH-px, GSH and GR, which play important roles in cellular antioxidant activity $(48,49)$. The present study found that 3S, 3'S-AST could decrease the content of MDA and increase GSH-px, GSH and GR activity levels in the H9c2 cells. The results indicated that 10 and $20 \mu \mathrm{M} 3 \mathrm{~S}, 3$ 'S-AST could improve the antioxidant ability of cardiomyocytes, inhibit excessive ROS accumulation and the occurrence of lipid peroxidation induced by oxidative damage. Apoptosis-related proteins, such as $\mathrm{Bax}, \mathrm{Bcl}-2$, caspase-3 and $\mathrm{p} 53$ play vital roles in cardiomyocyte damage $(50,51)$. The present study showed that myocardial apoptosis was significantly inhibited by $3 \mathrm{~S}, 3$ 'S-AST. In addition, the pro-apoptotic proteins Bax and caspase-3 were significantly upregulated, while the anti-apoptotic protein Bcl-2 was significantly decreased in $\mathrm{H}_{2} \mathrm{O}_{2}$-treated H9c2 cells. Treatment with $3 \mathrm{~S}, 3$ 'S-AST inhibited the increase of Bax, caspase- 3 and cleaved-caspase- 3 and the decrease of $\mathrm{Bcl}-2$ protein expression.

The NKA was discovered as an ion pump for moving $\mathrm{Na}^{+}$ and $\mathrm{K}^{+}$across the cell membrane $\sim 60$ years ago (52). It is a key enzyme in maintaining the cellular $\mathrm{Na}^{+}$and $\mathrm{K}^{+}$ion gradient in human cardiac myocytes (53). In addition to its ion pumping function, NKA also serves as a scaffold protein, interacting with neighboring proteins and facilitating multiple cell signaling pathways. Wang et al (22) reported that endogenous cardiotonic steroids could activate the NKA/Src/Erk1/2 receptor complex to increase ROS levels, and ROS act as endogenous cardiotonic steroids to stimulate NKA/Src/Erk1/2 activation. Inhibition of the NKA/Src/Erk1/2/ROS amplification loop exhibited a beneficial effect on I/R injury (23). The present study found that $3 \mathrm{~S}, 3$ 'S-AST could reduce ROS generation induced by $\mathrm{H}_{2} \mathrm{O}_{2}$, and exerted antioxidant effects by restoring the activation of antioxidant enzymes.

The NKA receptor not only acts as an ion pump, maintains cell membrane potential and stabilizes cell volume, but also participates in a variety of protein-protein interactions, which activates a number of protein cascades and participate in a variety of signal transductions, including Raf/MEK/ERK, phospholipase $\mathrm{C}$ /protein kinase $\mathrm{C}$, PI3K/Akt, $\mathrm{Ca}^{2+}$ signal transduction and ROS production (54). However, a number of studies have shown that these signal transduction pathways can often cross-react and generate specific cell regulation according to different signal stimulation. Wu et al (55) PI3K signaling could be stimulated by NKA with or without the presence of Src. Src inhibitors can downregulate PI3K signaling in cells treated with ouabain. Haas et al (56) showed that Src regulate interactions between NKA and EGFR, resulting in activated Ras/MAPK kinases cascade reaction. Further study will be performed to investigate the effects of AST on other signaling pathways, such as Raf/MEK/ERK or PI3K/Akt.

Decrease of Src and Erk1/2 phosphorylation levels could inhibit ROS generation, and p-Src and p-Erk1/2 were reduced by pNaKtide, which showed a cardioprotective effect in I/R injury (23). In the present study, treatment with $\mathrm{H}_{2} \mathrm{O}_{2}$, for 1 and $24 \mathrm{~h}$ significantly upregulated the levels of p-Src and p-Erk1/2. Pretreatment with 3S, 3'S-AST attenuated the activation of Src and Erk1/2 induced by $\mathrm{H}_{2} \mathrm{O}_{2}$; however, NKA protein expression levels were not changed. The present study demonstrated that 3S, 3'S-AST could inhibit oxidative stress injury of myocardial cells by reducing the NKA/Src/Erk1/2/ROS amplification signaling pathway.

In conclusion, 3S, 3'S-AST could inhibit ROS production and apoptosis by inhibiting the activation of Src and Erk1/2, and associated oxidant amplification signaling in myocardial cells following ROS treatment. The current study showed the therapeutic effects of 3S, 3'S-AST and its potential to be developed as a clinical approach for oxidative stress-related myocardial cell injury.

\section{Acknowledgements}

Not applicable.

\section{Funding}

This study was supported in part by the Nature Science Foundation of Zhejiang Province (grant no. LQ18H260003), the Technology Program of Zhejiang Province (grant no. 2017F30001), Key Subjects of Nutrition of Zhejiang Province (grant no. 16-zc03), Key Research and Development Program of Zhejiang Province (grant no. 2019C02028) and Zhejiang Provincial Bureau of Traditional Chinese Medicine (grant no. 2019ZZ005).

\section{Authors' contributions}

$\mathrm{XQ}$ and $\mathrm{YW}$ designed the project and supervised all research. XQ wrote the manuscript. ZZ, WH, ML, BZ, LZ, SM, ZH, DL, ZL and JC performed all experiments and analyzed data. All authors read and approved the final manuscript.

\section{Availability of data and materials}

The datasets used and/or analyzed during the current study are available from the corresponding author on reasonable request.

\section{Ethics approval and consent to participate}

Not applicable. 


\section{Patient consent for publication}

Not applicable.

\section{Competing interests}

The authors declare that they have no competing interests.

\section{References}

1. Ong SB, Hernández-Reséndiz S, Crespo-Avilan GE Mukhametshina RT, Kwek XY, Cabrera-Fuentes HA and Hausenloy DJ: Inflammation following acute myocardial infarction: Multiple players, dynamic roles, and novel therapeutic opportunities. Pharmacol Ther 186: 73-87, 2018.

2. Hausenloy DJ and Yellon DM: Myocardial ischemia-reperfusion injury: A neglected therapeutic target. J Clin Invest 123: 92-100, 2013.

3. Xie B, Liu X, Yang J, Cheng J, Gu J and Xue S: PIAS1 protects against myocardial ischemia-reperfusion injury by stimulating PPAR $\gamma$ SUMOylation. BMC Cell Biol 19: 24, 2018.

4. Sies H: Hydrogen peroxide as a central redox signaling molecule in physiological oxidative stress: Oxidative eustress. Redox Biol 11: 613-619, 2017.

5. Yu D, Li M, Tian Y, Liu J and Shang J: Luteolin inhibits ROS-activated MAPK pathway in myocardial ischemia/reperfusion injury. Life Sci 122: 15-25, 2015.

6. Guo J, Wang SB, Yuan TY, Wu YJ, Yan Y, Li L, Xu XN, Gong LL, Qin HL, Fang LH and Du GH: Coptisine protects rat heart against myocardial ischemia/reperfusion injury by suppressing myocardial apoptosis and inflammation. Atherosclerosis 231 : 384-391, 2013.

7. Mokhtari-Zaer A, Marefati N, Atkin SL, Butler AE and Sahebkar A: The protective role of curcumin in myocardial ischemia-reperfusion injury. J Cell Physiol 234: 214-222, 2018.

8. Faraone I, Sinisgalli C, Ostuni A, Armentano MF, Carmosino M, Milella L, Russo D, Labanca F and Khan H: Astaxanthin anticancer effects are mediated through multiple molecular mechanisms: A systematic review. Pharmacol Res 155: 104689, 2020.

9. Alam MN, Hossain MM, Rahman MM, Subhan N, Mamun MAA, Ulla A, Reza HM and Alam MA: Astaxanthin prevented oxidative stress in heart and kidneys of isoproterenol-administered aged rats. J Diet Suppl 15: 42-54, 2018.

10. Fang Q, Guo S, Zhou H, Han R, Wu P and Han C: Astaxanthin protects against early burn-wound progression in rats by attenuating oxidative stress-induced inflammation and mitochondria-related apoptosis. Sci Rep 7: 41440, 2017.

11. Coombes JS, Sharman JE and Fassett RG: Astaxanthin has no effect on arterial stiffness, oxidative stress, or inflammation in renal transplant recipients: A randomized controlled trial (the XANTHIN trial). Am J Clin Nutr 103: 283-289, 2016.

12. Xu L, Zhu J, Yin W and Ding X: Astaxanthin improves cognitive deficits from oxidative stress, nitric oxide synthase and inflammation through upregulation of PI3K/Akt in diabetes rat. Int J Clin Exp Pathol 8: 6083-6094, 2015.

13. Kim YJ, Kim YA and Yokozawa T: Protection against oxidative stress, inflammation, and apoptosis of high-glucose-exposed proximal tubular epithelial cells by astaxanthin. J Agric Food Chem 57: 8793-8797, 2009.

14. Ambati RR, Phang SM, Ravi S and Aswathanarayana RG: Astaxanthin: Sources, extraction, stability, biological activities and its commercial applications-a review. Mar Drugs 12: 128-152, 2014.

15. Kishimoto Y,YoshidaHandKondoK: Potentialanti-atherosclerotic properties of astaxanthin. Mar Drugs 14: 35, 2016.

16. Zhang ZW, Xu XC, Liu T and Yuan S: Mitochondrion-permeable antioxidants to treat ROS-burst-mediated acute diseases. Oxid Med Cell Longev 2016: 6859523, 2016.

17. Shi Y, Lin P, Wang X, Zou G and Li K: Sphingomyelin phosphodiesterase 1 (SMPD1) mediates the attenuation of myocardial infarction-induced cardiac fibrosis by astaxanthin. Biochem Biophys Res Commun 503: 637-643, 2018.

18. Belliard A, Sottejeau Y, Duan Q, Karabin JL and Pierre SV: Modulation of cardiac $\mathrm{Na}^{+}, \mathrm{K}^{+}$-ATPase cell surface abundance by simulated ischemia-reperfusion and ouabain preconditioning. Am J Physiol Heart Circ Physiol 304: H94-H103, 2013.
19. Li Z and Xie Z: The Na/K-ATPase/Src complex and cardiotonic steroid-activated protein kinase cascades. Pflugers Arch 457: 635-644, 2009

20. Yan Y, Shapiro AP, Haller S, Katragadda V, Liu L, Tian J, Basrus V, Malhotra D, Xie Z, Abraham NG, et al: Involvement of reactive oxygen species in a feed-forward mechanism of $\mathrm{Na} / \mathrm{K}-\mathrm{ATP}$ ase-mediated signaling transduction. J Biol Chem 288: 34249-34258, 2013.

21. Liu J, Tian J, Haas M, Shapiro JI, Askari A and Xie Z: Ouabain interaction with cardiac $\mathrm{Na}^{+} / \mathrm{K}^{+}$-ATPase initiates signal cascades independent of changes in intracellular $\mathrm{Na}^{+}$and $\mathrm{Ca}^{2+}$ concentrations. J Biol Chem 275: 27838-27844, 2000.

22. Wang Y, Ye Q, Liu C, Xie JX, Yan Y, Lai F, Duan Q, Li X, Tian $\mathbf{J}$ and Xie Z: Involvement of Na/K-ATPase in hydrogen peroxide-induced activation of the Src/ERK pathway in LLC-PK1 cells. Free Radic Biol Med 71: 415-426, 2014.

23. Li H, Yin A, Cheng Z, Feng M, Zhang H, Xu J, Wang $F$ and Qian L: Attenuation of Na/K-ATPase/Src/ROS amplification signal pathway with pNaktide ameliorates myocardial ischemia-reperfusion injury. Int J Biol Macromol 118: 1142-1148, 2018.

24. Ding S, Liu D, Wang L, Wang G and Zhu Y: Inhibiting MicroR NA-29a protects myocardial ischemia-reperfusion injury by targeting SIRT1 and suppressing oxidative stress and NLRP3-mediated pyroptosis pathway. J Pharmacol Exp Ther 372: 128-135, 2020.

25. Karu I, Tähepõld P, Ruusalepp A and Starkopf J: Pretreatment by hyperoxia-a tool to reduce ischaemia-reperfusion injury in the myocardium. Curr Clin Pharmacol 5: 125-132, 2010.

26. Cadenas S: ROS and redox signaling in myocardial ischemia-reperfusion injury and cardioprotection. Free Radic Biol Med 117: 76-89, 2018.

27. Wang L, Lin R, Guo L and Hong M: Rosuvastatin relieves myocardial ischemia/reperfusion injury by upregulating PPAR- $\gamma$ and UCP2. Mol Med Rep 18: 789-798, 2018.

28. Hoffman JJ Jr, Gilbert TB, Poston RS and Silldorff EP Myocardial reperfusion injury: Etiology, mechanisms, and therapies. J Extra Corpor Technol 36: 391-411, 2004.

29. Visioli F and Artaria C: Astaxanthin in cardiovascular health and disease: Mechanisms of action, therapeutic merits, and knowledge gaps. Food Funct 8: 39-63, 2017.

30. Lauver DA, Lockwood SF and Lucchesi BR: Disodium Disuccinate Astaxanthin (Cardax) attenuates complement activation and reduces myocardial injury following ischemia/reperfusion. J Pharmacol Exp Ther 314: 686-692, 2005.

31. Shah MM, Liang $Y$, Cheng JJ and Daroch $M$ : Astaxanthin-producing green microalga Haematococcus pluvialis: From single cell to high value commercial products. Front Plant Sci 7: 531, 2016.

32. EFSA Panel on Dietetic Products, Nutrition and Allergies (NDA): Scientific opinion on the safety of astaxanthin-rich ingredients (AstaREAL A1010 and AstaREAL L10) as novel food ingredients. EFSA J: 15 July, 2014 (Epub ahead of print). doi: org/10.2903/j.efsa.2014.3757.

33. Iwamoto T, Hosoda K, Hirano R, Kurata H, Matsumoto A, Miki W, Kamiyama M, Itakura H, Yamamoto S and Kondo K: Inhibition of low-density lipoprotein oxidation by astaxanthin. J Atheroscler Thromb 7: 216-222, 2000.

34. Yoshida H, Yanai H, Ito K, Tomono Y, Koikeda T, Tsukahara H and Tada N: Administration of natural astaxanthin increases serum HDL-cholesterol and adiponectin in subjects with mild hyperlipidemia. Atherosclerosis 209: 520-523, 2010.

35. Ruen-Ngam D, Shotipruk A and Pavasant P: Comparison of extraction methods for recovery of astaxanthin from Haematococcus pluvialis. Sep Sci Technol 46: 64-70, 2010.

36. Zhu S, Wang T, Luo F, Li H, Jia Q, He T, Wu H and Zou T: Astaxanthin inhibits proliferation and induces apoptosis of LX2 cells by regulating the miR29b/Bcl2 pathway. Mol Med Rep 19: 3537-3547, 2019

37. Fan CD, Sun JY, Fu XT, Hou YJ, Li Y, Yang MF, Fu XY and Sun BL: Astaxanthin attenuates homocysteine-induced cardiotoxicity in vitro and in vivo by inhibiting mitochondrial dysfunction and oxidative damage. Front Physiol 8: 1041, 2017.

38. Okada Y, Ishikura M and Maoka T: Bioavailability of astaxanthin in Haematococcus algal extract: The effects of timing of diet and smoking habits. Biosci Biotechnol Biochem 73: 1928-1932, 2009

39. Qiao X, Yang L, Zhang T, Zhou Q, Wang Y, Xu J and Xue C: Synthesis, stability and bioavailability of astaxanthin succinate diester. J Sci Food Agric 98: 3182-3189, 2018. 
40. Mercke OJ,Lignell A, Pettersson A and Hoglund P: Oral bioavailability of the antioxidant astaxanthin in humans is enhanced by incorporation of lipid based formulations. Eur J Pharm Sci 19: 299-304, 2003

41. Barros MP, Marin DP, Bolin AP, de Cássia Santos Macedo R, Campoio TR, Fineto C Jr, Guerra BA, Polotow TG, Vardaris C, Mattei R and Otton R: Combined astaxanthin and fish oil supplementation improves glutathione-based redox balance in rat plasma and neutrophils. Chem-Biol Interact 197: 58-67, 2012.

42. Rao AR, Reddy RLR, Baskaran V, Sarada R and Ravishankar GA: Characterization of microalgal carotenoids by mass spectrometry and their bioavailability and antioxidant properties elucidated in rat model. J Agr Food Chem 58: 8553-8559, 2010.

43. Satoh A, Tsuji S, Okada Y, Murakami N, Urami M, Nakagawa K, Ishikura M, Katagiri M, Koga Y and Shirasawa T: Preliminary clinical evaluation of toxicity and efficacy of a new astaxanthin-rich Haematococcus pluvialis extract. J Clin Biochem Nutr 44: 280-284, 2009

44. Baburina Y, Krestinin R, Odinokova I, Sotnikova L, Kruglov A and Krestinina O: Astaxanthin inhibits mitochondrial permeability transition pore opening in rat heart mitochondria. Antioxidants (Basel) 8: 576, 2019.

45. Nakao R, Nelson OL, Park JS, Mathison BD, Thompson PA and Chew BP: Effect of astaxanthin supplementation on inflammation and cardiac function in BALB/c mice. Anticancer Res 30 2721-2725, 2010

46. Kalogeris T, Bao Y and Korthuis RJ: Mitochondrial reactive oxygen species: A double edged sword in ischemia/reperfusion vs preconditioning. Redox Biol 2: 702-714, 2014

47. Ma JJ, Yu YG, Yin SW, Tang CH and Yang XQ: Cellular uptake and intracellular antioxidant activity of Zein/Chitosan nanoparticles incorporated with quercetin. J Agric Food Chem 66: 12783-12793, 2018.
48. Goc Z, Szaroma W, Kapusta E and Dziubek K: Protective effects of melatonin on the activity of SOD, CAT, GSH-Px and GSH content in organs of mice after administration of SNP. Chin J Physiol 60: 1-10, 2017.

49. Couto N, Wood J and Barber J: The role of glutathione reductase and related enzymes on cellular redox homoeostasis network. Free Radic Biol Med 95: 27-42, 2016.

50. Lopez-Neblina F, Toledo AH and Toledo-Pereyra LH: Molecular biology of apoptosis in ischemia and reperfusion. J Invest Surg 18: 335-350, 2005.

51. Eefting F, Rensing B, Wigman J, Pannekoek WJ, Liu WM, Cramer MJ, Lips SJ and Doevendans PA: Role of apoptosis in reperfusion injury. Cardiovasc Res 61: 414-426, 2004.

52. Skou JC: The influence of some cations on an adenosine triphosphatase from peripheral nerves. Biochim Biophys Acta 23: 394-401, 1957.

53. Pierre SV and Xie Z: The Na,K-ATPase receptor complex: Its organization and membership. Cell Biochem Biophys 46: 303-316, 2006.

54. Cui X and Xie Z: Protein interaction and $\mathrm{Na} / \mathrm{K}-\mathrm{ATPase}-$ mediated signal transduction. Molecules 22: 990, 2017.

55. Wu J, Akkuratov EE, Bai Y, Gaskill CM, Askari A and Liu L: Cell signaling associated with $\mathrm{Na}(+) / \mathrm{K}(+)$-ATPase: Activation of phosphatidylinositide 3-kinase IA/Akt by ouabain is independent of Src. Biochemistry 52: 9059-9067, 2013.

56. Haas M, Wang H, Tian J and Xie Z: Src-mediated inter-receptor cross-talk between the $\mathrm{Na}^{+} / \mathrm{K}^{+}$-ATPase and the epidermal growth factor receptor relays the signal from ouabain to mitogenactivated protein kinases. J Biol Chem 277: 18694-18702, 2002.

This work is licensed under a Creative Commons Attribution-NonCommercial-NoDerivatives 4.0 International (CC BY-NC-ND 4.0) License. 